\title{
Theoretical Perspectives on the Outsourcing Delegate in Personal Wealth Management
}

\author{
Jao-Hong Cheng \\ National Yunlin University of Science \& Technology \\ E-Mail: jhcheng@yuntech.edu.tw \\ Huei-Ping Chen \\ National Yunlin University of Science \& Technology \\ E-Mail: g9623802@yuntech.edu.tw \\ Chih-Ming Lee \\ National Yunlin University of Science \& Technology \\ E-Mail: purplejoey@hotmail.com \\ Yueh-Hsiu Liao \\ National Yunlin University of Science \& Technology \\ E-Mail: g9423213@yuntech.edu.tw \\ Shu-Nu Chan \\ National Yunlin University of Science \& Technology \\ E-Mail: g9323205@yuntech.edu.tw
}

\begin{abstract}
Despite the fact that several finance case studies have investigated the performance to personal wealth outsourcing, little is known about how specific performance of personal wealth management illustrate with multi-theories. We apply a multiple perspective approach to explore theories of transaction cost, third party agent, resource-reliance, cooperative relationship, and performance efficacy. Our results indicate that most of these factors indeed significantly influence the degree of integration in cooperation relationship to lead the performance of personal wealth management. In particular, our study offers a theoretical rationale for why reactions to
\end{abstract}


personal wealth outsourcing may occur, while providing practitioners with several means by which they can increase the value of outsourcing service.

Keywords: Transaction Costs Theory, Agency Theory, Resource-Dependence Theory, Wealth Management, Cooperation Relationship, Structural Equation Modeling (SEM)

\section{INTRODUCTION}

The research results of the international wealth, conducted by Merrill Lynch and Cap Gemini Ernst \& Young indicate that over 7.7 million people held more than US $\$ 1$ million of current assets and total assets values were as high as US\$28.8 trillion in 2003. It is estimated that total assets will increase to approximately US $\$ 40$ trillion by the end of 2008 with 7\% growth rate per year.

According to Asian Wealth Survey 2004 ${ }^{1}$, Citigroup pointed out that during the last decade, Taiwan family assets had steady growth and family wealth was as high as US\$809 billion in 2003 which was higher than the GDP 2.6 time of growth and also near ten year new high. Under the synchronous growth in the personal assets of Taiwan, wealth management market is full of business opportunities and potentials. Moreover, the research shows that Taiwan family investments through professional management increase by $12 \%$ annually, well which lead an annually average growth rate of $5 \%$ in self-managed assets. It is clear that Taiwan investors have gradually entrusted investments to professional wealth management outsourcing unit.

Bank's wealth management businesses preponderate in relevant literatures concerning worldwide wealth management (Drake, L. and Hall, M. J. B., 2003), which are often seen in cases with empirical study and less explained in theoretical frameworks. Therefore, the research is designed to construct the mode of cooperation relationship in personal wealth management outsourcing within a theoretical framework. The research is focused on its theme from multi-theoretical viewpoints and investigates the relationship among transaction cost theory, agency theory, resource-dependence theory, and cooperation relationship in personal wealth management services as well as its performance.

\footnotetext{
1 It was from Citibank Press Release July 92003.
} 


\section{LITERATURE REVIEW}

\section{Cooperation Relationship}

In the process of offering services, professionally trained financing specialists establish cooperation relationship with their clients. The cooperation relationship refers to an interconnected mode in different nodes for the same object, which is to create interests for both parties and more. For example, according to Kumar et al. (1995), when upstream enterprises and downstream dealers both contribute each other and confront high barriers to entry, each partner has a strong motive to establish and maintain their relations. Any such identify of interest relationship make each partner realize that they are in win-win situation and can establish cooperation relationship which is most favorable for them under the circumstances.

In the research, the so-called cooperation relationship refers to closeness of cooperation relationship between the individual and wealth management outsourcing unit. Relative studies points out that cooperation relationship varies according to its closeness.

\section{Transaction Cost Theory}

Transaction cost analysis is to apply economic viewpoints to explain a global transaction. According to Coase (1937), any commercial and non-commercial transactions involve the three costs: search cost, contracting cost and coordination cost.

As time goes by, the New Institutional Economics has gradually replaced traditionally New Classical Economics. Although the New Classical Economics has ignored the concept of "corporation" and even regarded it as the generative function (Rindfleisch and Heide, 1997), the transaction cost analysis regards the "corporation" as a managerial structure.

To save on cost, continuous expansion is allowed and thus the interior framework of a corporation is also constantly on the expansion until the internal operating costs exceed the external costs. According to Coase (1937), after the division of labor in the production process, if transaction coordination costs through the market are excessive, then the coordination work should be turned into the internal management to the organization, that is to say, the business scope of an organization is affected by the size of transaction costs.

Williamson (1975) and Kogut (1988) think the cooperation relationship is also an exchange. If Transaction Cost plus External Cost are less than Internalized Cost and 
the two sides are willing to internalize external resources, then the cooperation relationship will be established between both sides. Furthermore, the most important purpose of organizational cooperation is to reduce the transaction costs and risks of operation activities and avoid unnecessary investing activities. Arising from Transaction Cost's viewpoint, the intent of the cooperation is to reduce the transaction costs of operation activities, which represent some specific motives such as: reduce costs, allocate risks, avoid unnecessary repeated investments, and gain economics of scale.

According to Miller (1992), the uncertainty means that individuals or organizations realize they lack adequate capabilities of exactly predicting something. An individual or organization knows they lack sufficient information to make exact prediction, or they find themselves unable to correctly distinguish between relevant and irrelevant information, that is to say, they encounter uncertain problems. Environmental uncertainty means that uncertain resources are external environment of an organization. Therefore, the so-called environmental uncertainty refers to the influence of uncertain environment on network performance, the unpredictability of organization variables, or improper/inadequate information related with organization variables.

\section{Agency Theory}

The essence of outsourcing is an exchange. According to Arrow (1985), the agency relationship is one of particular factors in most transactions/exchanges; in financial system, the existence of agency relationship is because there is growing recognition for professional knowledge and talented persons. Many scholars think agency theory has an enormous capacity for explaining why the organizations exist and how they operate (Hesterly et al., 1990).

When principals rely on their agents to take some actions for their interests, agency problems will occur (Jensen and Meckling, 1976 ; Bergen et al., 1992). Agents use some resources of principals to distribute and sell their products or services, and the goals of principals and agents should be satisfied under the terms of an agreement, so there is an agency relationship in the above case. The agency relationship also exists in the employer-employee relationship within an organization and inter-organizational division of labor and cooperation. Therefore, the agency relationship is formed between individuals and authorized agencies (e.g. the corporation). 


\section{Resource-Dependence Theory}

The main perspective of Resource-Dependence Theory is that the exchange with the outside can gain resources needed for life. Therefore, the interdependence and power relationship exist between two organizations; that is to say, organizations must depend on resources to ensure their survival. In order to gain resources, organizations must interact with external resource controllers, hence the need for dependence on their environment.

According to the perspective of Resource-Dependence Theory, when organizations face the exchange of resources and externally environmental uncertainty, they will tend to connect with important production factors in external environment, which results in the occurrence of cooperation relationship (Pfeffer and Gerald, 1978). Meaning to say, after the establishment of the cooperation relationship, one organization can appropriate others' resources for its own use. Therefore, the cooperation relationship has the function of mutual supplement with each other's resources. Meanwhile, the interdependence will occur between two organizations.

\section{Performance Evaluation of Personal Financing Management Outsourcing}

Teigen (1997) performance evaluation refers to the performance measurement system and the strategy design as the grounds for a subsequent improvement. A study of individual level (Mitra, Gupta, and Jenkins, 1997; Rambo and Pinto, 1989) verifies the effective difference in the compensation and show that the performance will increase with increasing gap in the compensation amount (Ehrenberg and Bognanno, 1990). When uncertainty of external environment is greater, the marginal cost invested by investors will increase with increasing uncertainty. Pfeffer and Langton (1993) find that the bigger the gap in the compensation amount and the lower personal satisfactory and cooperation willingness.

The research adopts the viewpoint of Beamon (1998) that qualitative and quantitative measurement indices of financing management outsourcing performance should be combined and the individual performance measurements should be integrated to form a performance measurement system. Multiple performance indices proposed by the scholars above are used as the measuring variables of the features of financing management outsourcing performance in the research so as to learn the association between personal financing management outsourcing and cooperation relationship. 


\section{RESEARCH MODEL AND HYPOTHESES}

After reviewing relative literatures and investigating the framework of the main concept in the research, the core of the study lies in the cooperation relationship between individuals and Wealth management outsourcing unit. Besides, the exploration of literatures brings forward some similar viewpoints with the theory. For interpreting determinants and performance of cooperation relationship, the research describes its framework based on theoretical viewpoints (See Figure 1).

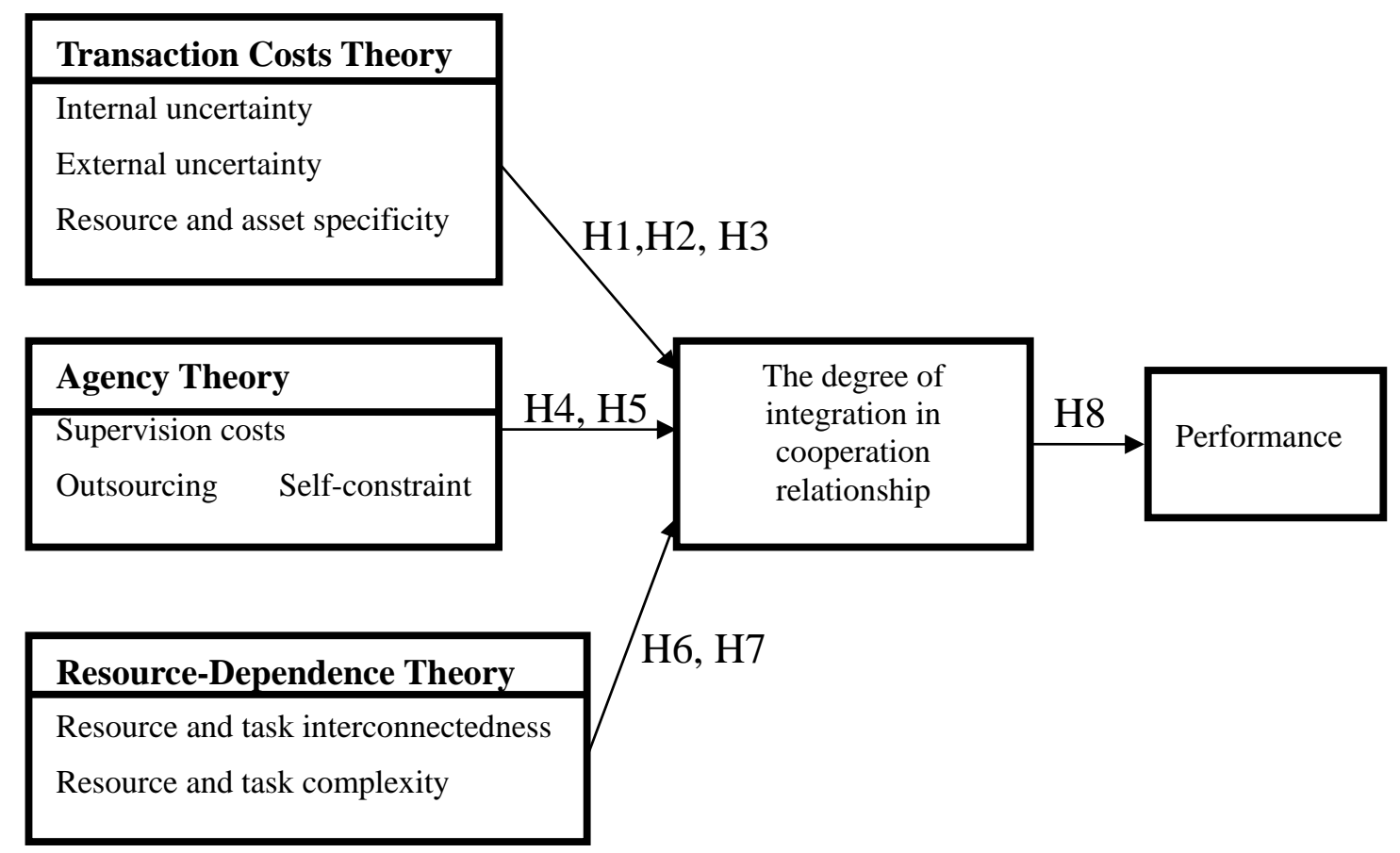

Figure 1 Research Model

\section{Hypotheses Development}

The customized financial services aim at achieving wealth preservation and wealth recreation through international finance adviser and investment adviser. With liberalization and internationalization of the financial market, personal financial management must depend on relevant knowledge of the financing plan such as trust, law and tax. And generally, personal financing and investment is facing higher difficulties. Furthermore, according to Hallikas et al. (2002), if the decisions are made in uncertain and complex conditions, the costs will be higher and the risks will be bigger. When the environmental uncertainty within organizations is higher, the cooperation relationship tends to be closer. Therefore, the environmental uncertainty 
can interpret the features of the cooperation relationship between individuals and organizations.

H1: When individuals perceive significantly higher degrees of the environmental uncertainty, they tend to establish closer cooperation relationship.

H2: When individuals perceive significantly higher degrees of the uncertainty existed in their financing capacity, they tend to establish closer cooperation relationship.

The specified investment refers to an asset that is not transferred to others and doesn't service other purposes, the degree of which is higher, and then asset specificity is higher. And the value of the asset depends on the degree of continuance of specified transaction relations. Once the transaction relations terminate, the asset will lose its value, and the benefits resulted from the asset are difficult to be gained from other transaction relations. Furthermore, according to Williamson $(1975,1985$, 1991), the specified investment both sides of the transaction in specific transaction relations so as to reduce the occurrence of opportunism. Thus, we hypothesize that higher professional financing will be associated with the closer cooperation relationship.

H3: When individuals perceive significantly higher degrees of the asset specificity in professional financing, they tend to establish closer cooperation relationship.

According to Chongcheng Lin (2002), in division of modern business management specialties, individuals or corporations certainly have unique competitive advantages for surviving in fierce competition. However, in corporation resources, the most desirable assets of a corporation are know-how, the resources bringing it with competitive advantages. Therefore, corporations must rely on other organizations' database to provide professionally processed information for themselves, thereby supporting management decisions and ensuring management success.

H4: When the supervision costs of individuals spending on wealth management outsourcing unit are higher, they tend to establish closer cooperation relationship. 
According to Eisenhardt (1985), principals and agents may exist in different organizations, and they each have different objectives and labor staffing. Since principals and agents have different objectives and risk preference, agent problems such as monitoring costs, bonding costs and residual costs are bond to produce when staffs carefully consider self-interest motivation, limited rationality and risk avoidance. According to Fama and Jensen (1983), when the organization's ownership and control are separated, principals and agents will have a pattern of cooperation relationship which is formed due to mutual interest and risk sharing, and then either principal must control and constrain agents' behaviors or agents must be self-constraint so as to reduce principals' opportunity loss, namely so-called control-agent problem. Thus, the higher self-constraint costs are likely associated with the closer cooperation relationship.

H5: When the self-constraint costs of individuals spending on wealth management outsourcing unit are higher, they tend to establish closer cooperation relationship.

Pfeffer and Gerand (1978) point out that task interconnectedness refers to the state of interconnection between resources and organizations. Knemeyer el at. (2003) and Bowersox el at. (2000) continually use the concept of 'interconnectedness' and point out that resource interconnectedness is formed through the relationship between persons and persons or between organizations and organizations. Resulted, resource interconnectedness may be affected by some personally emotional factors and have an effect on the development of subsequent organizational relationship. Therefore, the researchers think the development of relationship between individuals and financing commissioners in wealth management outsourcing unit should be affected by task interconnectedness.

H6: When the extent to which personal wealth management professionally interconnects with wealth management outsourcing unit is higher, they tend to establish closer cooperation relationship.

Task complexity refers to the quantity of different and specific resources devoted for completing a product or service. Pfeffer and Gerand (1978) point out that if an organization wishes to carry out a complex task within the agreed period, it must be integrated with different expertise and experts, so the task complexity will result in the interdependence of interorganizational behaviors and the demand to add coordination activities. If the degree of each other's dependence in resource is higher, then the 
possibility of interaction occurred among organizations is higher. Meanwhile, the interchange of importance resources helps to early accomplishment of the complex task. Accordingly, it is hypothesized that:

H7: When the degree of complexity of individuals' investment task is higher, they tend to establish closer cooperation relationship.

According to Holm, Eriksson and Johanson (1996), when the degree of integration among partners is higher or transaction partners are willing to make further changes and adjustments for their cooperation relationship, coordination activities of both sides is more easily carried on and their united productivity is increased. Asanuma (1989) and Dyer (1996) point out that if the partner is willing to make specific investment and make integration in each other's specific resources, then the profits in the value chain will be increased.

Teigen (1997) performance evaluation refers to the performance measurement system and the strategy design as the grounds for a subsequent improvement. Kaplan and Norton (1996) propose that the ultimate aim of operation, investment and improvement to all organizations is to advance the financing performance. Therefore, the researchers think that one of key factors of wealth management outsourcing is to improve organizational performance. Thus,

H8: When the degree of integration in the cooperation relationship between individuals and wealth management outsourcing unit is higher, the performance of the cooperation relationship will also be better.

\section{RESEARCH METHOD}

Financing commissioners and salesmen are entrusted to dispatch 400 questionnaires to their clients in Taiwan. Altogether 281 questionnaires are returned, and the return rate reaches $70.25 \%$. Through careful investigation, 4 incomplete questionnaires are removed. There are 277 effective questionnaires and the return rate of effective questionnaires reaches 69.25\%. Moreover, there are 40 questionnaires returned by people without the experience of wealth management outsourcing, accounting for $14.44 \%$ of effective questionnaires returned; altogether 237 questionnaires are returned by people with the experience of wealth management outsourcing, accounting for $85.55 \%$ of effective questionnaires returned. 
SEM aims to examine the inter-related relationships simultaneously between a set of posited constructs, each of which is measured by one or more observed items (measures). We will do the confirmatory factor analysis and then further explore causal relationship among latent variables and validate the research hypotheses using the Structural Equation Modeling (SEM).

\section{RESULTS}

Under the theoretical concepts, the degree of the cooperation relationship between the factors of wealth management outsourcing unit and wealth management outsourcing unit as well as the analysis of the cooperation relationship and the performance both are tested from the hypothesis 1 to hypothesis 8 through $\gamma$ value of the model. And the significant correlation between the two is judged through $t$ value. The analysis results are shown in Table 1.

Since the internal uncertainty faced by individuals has an effect on the degree of cooperation relationship between individuals and wealth management outsourcing unit, under $\alpha=0.1$, the $\mathrm{H} 2$ can't be rejected.

The self-constraint costs of individuals spending on wealth management outsourcing unit are higher, they tend to establish closer cooperation relationship. $\alpha$ $=0.05$, the $\mathrm{H} 5$ can't be rejected.

The extent to which personal wealth management professionally interconnects with wealth management outsourcing unit is higher, they tend to establish closer cooperation relationship. When the degree of integration in the cooperation relationship between individuals and wealth management outsourcing unit is higher, the performance of the cooperation relationship is better. According to verification results, under $\alpha=0.01$, the hypothesis 6 and hypothesis 8 can't be rejected.

\section{CONCLUSION}

The paper establishes the model for causal association of the cooperation relationship between individuals and wealth management outsourcing unit and the performance based on transaction cost theory, agency theory and resource-dependence theory. The model is used to analyze how to utilize Wealth management outsourcing unit for the formation of closer cooperation relationship. The construction of the causal model is helpful to explain the combination of theory and practice of cooperation relationship between individuals and wealth management outsourcing unit. 
Table 1 Hypotheses test result

\begin{tabular}{|c|c|c|}
\hline & Hypotheses & $\begin{array}{c}\text { Parameter estimates } \\
\text { and } t \text { values }\end{array}$ \\
\hline H1 & $\begin{array}{l}\text { When individuals perceive significantly higher degrees } \\
\text { of the environmental uncertainty, they tend to establish } \\
\text { closer cooperation relationship. }\end{array}$ & $\begin{array}{l}-0.141 \\
(-0.614)\end{array}$ \\
\hline $\mathrm{H} 2$ & $\begin{array}{l}\text { When individuals perceive significantly higher degrees } \\
\text { of the uncertainty existed in their financing capacity, } \\
\text { they tend to establish closer cooperation relationship. }\end{array}$ & $\begin{array}{l}0.284 \\
(1.727)^{*}\end{array}$ \\
\hline H3 & $\begin{array}{l}\text { When individuals perceive significantly higher degrees } \\
\text { of the asset specificity in professional financing, they } \\
\text { tend to establish closer cooperation relationship. }\end{array}$ & $\begin{array}{l}0.063 \\
(0.592)\end{array}$ \\
\hline $\mathrm{H} 4$ & $\begin{array}{l}\text { When the supervision costs of individuals spending on } \\
\text { wealth management outsourcing unit are higher, they } \\
\text { tend to establish closer cooperation relationship. }\end{array}$ & $\begin{array}{l}-0.060 \\
(-0.393)\end{array}$ \\
\hline H5 & $\begin{array}{l}\text { When the self-constraint costs of individuals spending } \\
\text { on wealth management outsourcing unit are higher, } \\
\text { they tend to establish closer cooperation relationship. }\end{array}$ & $\begin{array}{l}0.307 \\
(1.983)^{* *}\end{array}$ \\
\hline H6 & $\begin{array}{l}\text { When the extent to which personal wealth management } \\
\text { professionally interconnects with wealth management } \\
\text { outsourcing unit is higher, they tend to establish closer } \\
\text { cooperation relationship. }\end{array}$ & $\begin{array}{l}0.632 \\
(3.251)^{* * *}\end{array}$ \\
\hline H7 & $\begin{array}{l}\text { When the degree of complexity of individuals' } \\
\text { investment task is higher, they tend to establish closer } \\
\text { cooperation relationship. }\end{array}$ & $\begin{array}{l}0.083 \\
(0.758)\end{array}$ \\
\hline H8 & $\begin{array}{l}\text { When the degree of integration in the cooperation } \\
\text { relationship between individuals and wealth } \\
\text { management outsourcing unit is higher, the } \\
\text { performance of the cooperation relationship will also } \\
\text { be better. }\end{array}$ & $\begin{array}{l}0.617 \\
(7.534) * * *\end{array}$ \\
\hline
\end{tabular}

Note: in the parentheses is the t-value

*Represent $\mathrm{p}<0.1$; ** Represent $\mathrm{p}<0.05$; *** Represent $\mathrm{p}<0.01$

In accordance with the results of empirical hypotheses of transaction cost theory in the research, when individuals perceive significantly higher degree of the uncertainty existed in their financing capacity, they tend to establish closer 
cooperation relationship. When the uncertainty faced by individuals is higher, individuals may perform higher degree of cooperation relationship with wealth management outsourcing unit. About agency cost, when the self-constraint costs of individuals spending on wealth management outsourcing unit are higher, they tend to establish closer cooperation relationship. The self-constraint costs of outsourcing unit are invested to reduce the cooperation risk so as to advance the cooperation relationship.

The results of empirical perspectives of resource-dependence theory in the research, when the extent to which personal wealth management professionally interconnects with wealth management outsourcing unit is higher, they tend to establish closer cooperation relationship. If individuals want to accomplish the investment task, they must effectively utilize important resources and establish interconnection with other organizations as well as harmonize the demand of activities. When the degree of integration in the cooperation relationship between individuals and wealth management outsourcing unit is higher, the performance of the cooperation relationship is better. The closer individuals have established the cooperation relationship with wealth management outsourcing unit, the better individuals have the investment performance.

Individual questionnaire items were designed to be unbiased but several items related individual privacy. Another limitation of this study is the lack of data on the quality of the information transparency. In addition, the sample has a slight bias in favor of more educated, affluent, and experience of personal wealth outsourcing individuals. Therefore, the results should be viewed with some caution.

\section{REFERENCES}

Arrow, K. (1985). The Economics of Agency, in Principals and Agents: The Structure of Business, J.W. Pratt and Zeckhauser, R. J. eds. Boston, MA: Harvard University Press.

Asanuma, B. (1989). Manufacturer-Supplier Relationships in Japan and the Concept of elation-Specific Skill. Journal of the Japanese and International Economies, 3(1), 1-30.

Beamon, B. M. (1998). Supply chain design analysis: Model and methods. International Journal of Production Economics, 1(18), 281-294.

Bergen, M., Dutta, S. and Walker, O., C. (1992). Agency Relationships in Marketing: A Review of the Implications and Applications of Agency and Related Theories. Journal of Marketing, 3, 1-24. 
Bowersox, D. J., David J. C., and Theodore P. S. (2000). Ten Mega-Trends That Will Revolutionize Supply Chain Logistic. Journal of Business Logistics, 21(2), 1-16. Chong-Cheng Lin (2002). A Study of Management of IT database and Marketing Model, Unpublished doctoral dissertation, National Taipei University, Taipei.

Coase, R. (1937). The Nature of the Firm, Economica, New Series, 4(16), 386-405.

Drake, L. and Hall, M. J. B. (2003). Efficiency in Japanese Banking: An Empirical Analysis. Journal of Banking and Finance, 27(5), 891-1079.

Dyer, J. H. (1996). How Chrysler Created an American Keiretsu. Harvard Business Review, July-August, 42-56.

Eisenhardt, K. M. (1985). Control: Organizational and Economic Approaches. Management Science, 31, 134-149.

Ehrenberg, R. G. and Bognanno, M. L. (1990). Do tournaments have incentive effects? Journal of political economy, 98(6), 1307-1324.

Fama, E. and Michael, J. (1983). Separation of Ownership and Control. Journal of Law \& Economics, 26, 301-325.

Hallikas, J., Virolainen, V. M. and Tuominen, M. (2002). Understanding Risk and Uncertainty in Supplier Networks--a Transaction Cost Approach. International Journal of Production Research, 40(15), 3519-3531.

Hesterly, W. S., Liebeskind, J., and Zenger, T. R. (1990). Organizational Economic: An Impending Revolution in Organization Theory? Academy of Management Review, 15(3), 409-410.

Holm, D. B., Eriksson, K. and Johanson, J. (1996). Business Networks and Cooperation in International Business Relationships. Journal of International Business Studies, Special Issue, 1033-1053.

Jensen, M. C. and Meckling, W. H. (1976). Theory of the Firm: Managerial Behavior, Agency Costs, and Ownership Structure. Journal of Financial Economics, 3(2), 305-360.

Knemeyer, A. M., Corsi, T. M. and Murphy, P. R. (2003). Logistics Outsourcing Relationships: Customer Perspectives. Journal of Business Logistics, 24(1), 77-109.

Kogut, B. (1988). Joint Ventures: Theoretical and Empirical Perspectives. Strategic Management Journal, 9, 319-332.

Kumar, N., Lisa K. S. and Jan-Benedict E. M. Steenkamp (1995). The Effect of Perceived Interdependence on Dealer Attitudes. Journal of Marketing Research, 32(3), 348-356. 
Mitra, A., Gupta, N., \& Jenkins, G.D. Jr. (1997). A drop in the bucket: When is a pay raise a pay raise? Journal of Organizational Behavior, 18, 117-137.

Miller, G. J. (1992). Managerial Dilemmas: The Political Economy of Hierarchy. Cambridge, New York, and Melbourne: Cambridge University Press.

Pfeffer, J. and Gerald, S. (1978). The External Control of Organizations: A Resource Dependence Perspective. New York: Harper and Row.

Pfeffer, J. and Langton, N. (1993). The Effect of Wage Dispersion on Satisfaction, Productivity, and Working Collaboratively: Evidence from College and University Faculty. Administrative Science Quarterly, 38(3), 382-407.

Rambo, W. W., and Pinto, J. N. (1989). Employee's perception of pay increases. Journal of Occupational Psychology, 62, 135-145.

Rindfleisch, Aric and Jan B. Heide (1997). Transaction cost analysis: Past, Present, and future applications. Journal of marketing, 61, 30-54.

Teigen, K. H. (1997). Luck, envy, and gratitude: It could have been different. Scandinavian Journal of Psychology, 38, 313-323.

Williamson, O. E. (1975). Markets and Hierarchies: Analysis and Antitrust Implication. New York: The Free Press.

Williamson, O. E. (1985). The Economic Institutions of Capitalism. New York: The Free Press.

Williamson, O. E. (1991). Comparative Economic Organization: The Analysis of Discrete Structural Alternatives. Administrative Science Quarterly, 36(2), 269-296. 